\title{
CHRYSOPHYCEAN STOMATOCYSTS FROM MORSKIE OKO AND ŻABIE OKO LAKES IN THE TATRA NATIONAL PARK, POLAND
}

\author{
JOLANTA CABAŁA \\ Department of Phycology \\ W. Szafer Institute of Botany, Polish Academy of Sciences \\ Lubicz 46, 31-512 Kraków, Poland \\ e-mail: cabala@ib-pan.krakow.pl \\ (Received: January 19, 2005. Accepted: August 17, 2005)
}

\begin{abstract}
Sixteen chrysophycean stomatocysts are reported from the lakes Morskie Oko and Żabie Oko in the Tatra National Park, Poland. Of these, six morphotypes are new to Poland, and two morphotypes plus one forma are new to science. These stomatocysts are illustrated with SEM micrographs and described according to International Statospore Working Group (ISWG) guidelines. The comparison of stomatocyst community between Morskie Oko and Żabie Oko lakes is given.
\end{abstract}

KEY WORDS: stomatocysts, algae, Chrysophytes, new morphotypes, Tatra National Park, Poland.

\section{INTRODUCTION}

This paper is a continuation of studies devoted to chrysophycean stomatocysts occurring in various water reservoirs in the Tatra National Park. The investigations started in 2003 because the area of Tatra Mts., with unique nature and numerous glacial lakes, was presumed to contain a remarkable stomatocyst composition. Previously only few data about cysts found in these mountains were reported in the phycological literature, e.g. by Wołoszyńska (1939), Szklarczyk-Gazdowa (1960) and Wasylik (1965). Alas, these authors provided only brief information about stomatocysts of chrysophycean algae co-occurring with other algae, but without precise descriptions or photographic documentation. In few cases they gave only line drawings, which are useless for identification of stomatocysts.

In 2003 numerous samples of water have been collected in various parts of the Tatra National Park, including Staw Toporowy Niżni lake, Staw Toporowy Wyżni peat bog, Źródło Lodowe spring, moss community with Palustriella commutata (Hedw.) Ochyra in the Dolina Kościeliska valley, Morskie Oko lake and Żabie Oko lake. The examination of stomatocyst composition in the Staw Toporowy Niżni lake revealed 36 stomatocysts, of which 7 were new to science, 10 new to Europe and 13 new to Poland (Cabała and Piątek 2004). Similar studies in the Staw Toporowy Wyżni peat bog have shown 31 stomatocysts, including 10 new to science, 5 new to Europe and 3 new to Poland (Cabała 2005). In the Źródło Lodowe spring and in the moss community with Palustriella commutata (Hedw.) Ochyra in the Dolina Kościeliska valley no stomatocysts have been detected, neither by LM and SEM studies. In opposition, in the Morskie Oko and Żabie Oko lakes the stomatocysts were observed and the results of their examination are shown and discussed in the present paper. Additionally, the state of studies on algae flora of the two lakes is briefly reviewed as follows:

Brief review on algal studies in the Morskie Oko and Żabie Oko lakes

Morskie Oko - Phycological studies in the Morskie Oko lake date back to the end of 19th century; the pioneering investigations were started by Józef Rostafiński, Eugen Daday and Roman Gutwiński (Siemińska 1970a). In that time Gutwiński $(1909,1913)$ recorded most numerous algae, giving information on about 215 taxa belonging mostly to Bacillariophyceae, Chlorophyta, Chrysophytes and Desmidiaceae. He included a number of species from the littoral and pelagial zones and distinguished algae characteristic for plankton of Morskie Oko lake. The very interesting taxonomical studies on Dinophyta were conducted by Wołoszyńska (1919, 1934, 1935, 1936, 1939, 1952), who described inter alia some taxa new for science, including Asterionella formosa Hass. var. tatrica Wołoszyńska, Mallomonas akrokosmos Ruttner fo. tatrica Wołoszyńska, Massartia schilleri Wołoszyńska, Gymnodinium frigidum Wołoszyńska, G. tatricum Wołoszyńska and G. polonicum Wołoszyńska. Next studies were made by Bilý (1941), Wasylik (1965) and Kawecka (1966). The latter author brought information on 131 taxa of Bacillariophyceae, 
Chlorophyta and Cyanophyta associated with leaves of $\mathrm{Po}$ tamogeton sp. floating on the water of Morskie Oko lake. Some remarkable algae were reported from this lake by Siemińska (1958, 1962, 1970a), who found among others such an interesting taxon as Bulbochaete basispora Wittrock \& Lundel. In the subsequent years she paid special attention to chrysophytes of Morskie Oko lake, listing two unusual species like Pseudokephyrion tatricum (Juriš) Starmach, Bitrichia chodatii (Reverdin) Chodat and describing one species new for science, Pseudokephyrion pawlowskii Siemińska (Siemińska 1970b). The real number of species of algae recorded so far in the Morskie Oko lake is hard to estimate because of different taxonomical concepts used during over one hundred years of studies on these organisms in the lake.

Żabie Oko - The algae flora of this lake is almost completely unknown. The only information on the extant algae from this small lake was found in the work of Wołoszyńska (1919), who reported one species of Dinophyta, viz. Gymnodinium tatricum. However, it should be mentioned that from the neighbouring Rybi Potok stream Kawecka
(1965, 1977) recorded 153 taxa of algae, of which $86.3 \%$ were diatoms, $6.3 \%$ green algae, $4.6 \%$ red algae, $1.3 \%$ yellow-brown algae and $0.6 \%$ aquatic fungi. In addition to these studies Wołowski et al. (2002) found six taxa of Pediastrum species in the fossil Quaternary sediments from the peat bog surrounding the Żabie Oko lake. Amongst them was Pediastrum orientale (Skuja) Jankovská \& Komárek, reported in that work for the first time from Poland.

\section{MATERIAL AND METHODS}

The material was collected on 23 August 2003 from two neighbouring lakes (Fig. 1) situated and characterized as follows:

1. Morskie Oko lake, lying at the $1395 \mathrm{~m}$ a.s.l., is the biggest and the most known lake in the Tatra Mts., located in the Dolina Rybiego Potoku valley. It covers an area of $34.93 \mathrm{ha}$ and is $862 \mathrm{~m}$ long and $566 \mathrm{~m}$ wide, with maximum depth of $50.8 \mathrm{~m}$ (medium $28.4 \mathrm{~m}$ ) (Wit-Jóźwikowa et al. 1962).
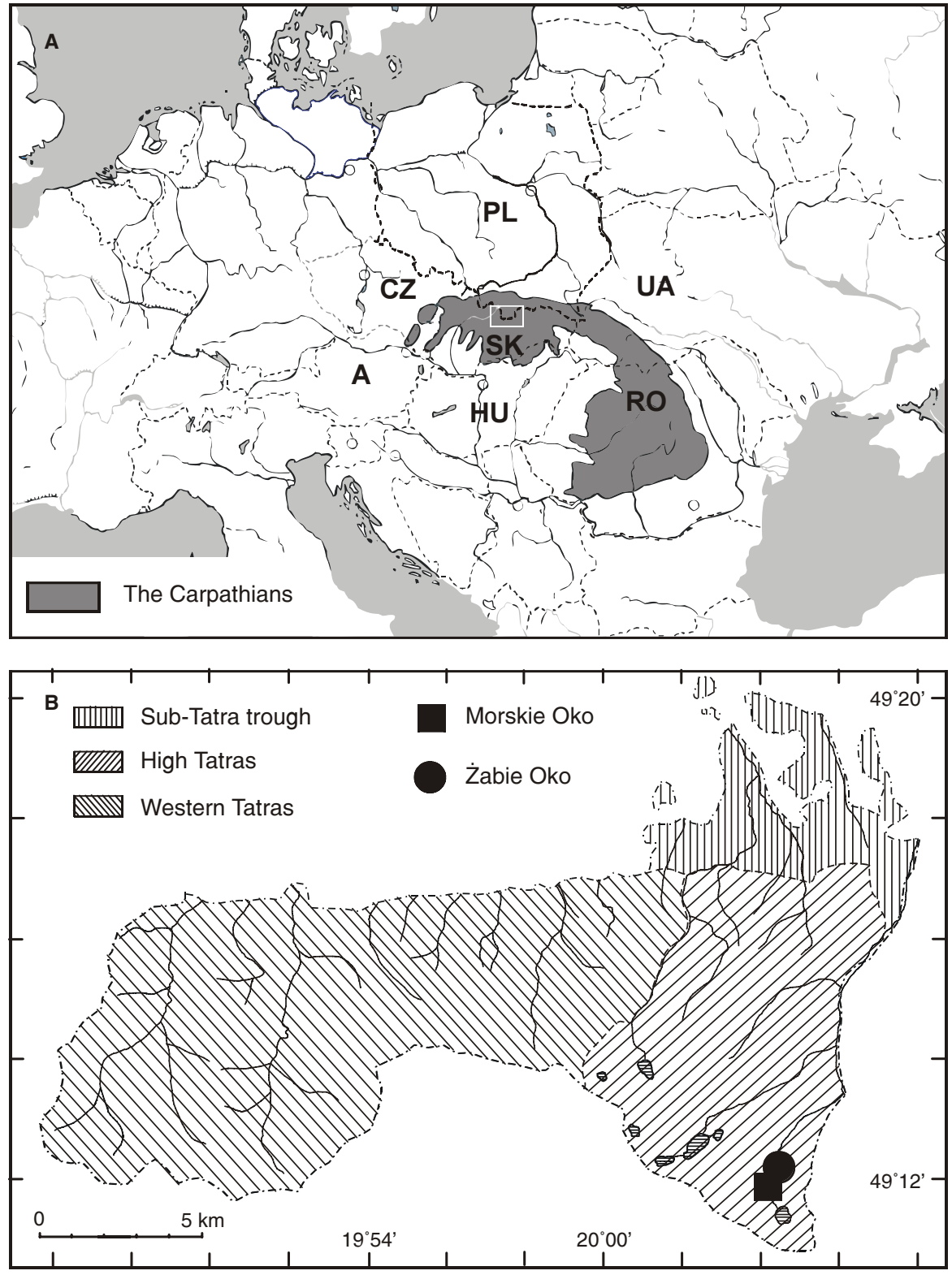

Fig. 1. A - location of the study area in the Carpathians. B - location of Morskie Oko and Żabie Oko lakes in the Tatra National Park. 
2. Żabie Oko lake, lying at the $1392.8 \mathrm{~m}$ a.s.1, is located in the Dolina Rybiego Potoku valley, north of the Morskie Oko lake. It covers an area of 0.2 ha with maximum depth of $3.3 \mathrm{~m}$ (medium $0.9 \mathrm{~m}$ ) (Wit-Jóźwikowa et al. 1962).

From each lake samples of water were collected into 120 $\mathrm{ml}$ plastic containers from four microhabitats, including (i) surface water, (ii) water from beneath the surface (30-40 $\mathrm{cm}$ deep), (iii) sediment from the bottom of the lakes (0-10 $\mathrm{cm}$ deep), and (iv) water squeezed from water plants (algal mats and mosses).

SEM-micrographs were taken in the Laboratory of Field Emission, Scanning Electron Microscopy and Microanalysis at the Institute of Geological Sciences of the Jagiellonian University. SEM-preparation was made as indicated in Cabała and Piątek (2004). Stomatocysts were measured and described from SEM-micrographs according to International Statospore Working Group (ISWG) guidelines (Cronberg and Sandgren 1986), and according to the taxonomy of Cabała (2002, 2003a, b), Cabała et al. (2004), Duff et al. (1995), Facher et al. (1996a, b), Vorobyova et al. (1996), van de Vijver et al. (1997a, b, 2000), Mrozińska et al. (1998), Hansen (2001), Kamenik et al. (2001), Pla (2001), Wilkinson et al. (2001) and Wołowski et al. (2004). New stomatocysts, not previously published, were assigned numbers from Cabała J. (Cabała 2005), beginning with stomatocyst \#29 Cabała J., and are cited as "this paper". Number of specimens refers to the number of SEMmicrographs used for the description of the stomatocysts. Negatives are deposited in the Iconotheca of Algae (KRAM) in the Department of Phycology of the W. Szafer Institute of Botany, Polish Academy of Sciences, Kraków.

\section{RESULTS}

Stomatocysts are presented in groups based on their shared morphological characters following Duff et al. (1995) and Wilkinson et al. (2001). Asterisks have been used to designate morphotypes that are new to Poland (*) and those that are described here for the first time $(* *)$.

\section{Unornamented stomatocysts}

Spherical, lacking collar:

Stomatocyst 9, Duff \& Smol 1988 emend. Zeeb \& Smol 1993 (Fig. 2)

Negative number: ZO/d-16.

Number of specimens: 3 .

Locality: Żabie Oko lake, sediment from the bottom (0-10 cm deep).

Description: This stomatocyst is a smooth, spherical, 8.4 $\mu \mathrm{m}$ in diameter. The pore is a regular, $0.7 \mu \mathrm{m}$ in diameter.

References: This stomatocyst has been found in Canada, U.S.A., Greenland (Duff et al. 1995), central Europe (Facher et al. 1996a), Czech Republic (Facher et al. 1996b), Austria (Kamenik et al. 2001), the Spanish part of Pyrenees (Pla 2001), Svalbard lakes (Betts-Piper et al. 2004) and in Poland (Cabała and Piątek 2004; Wołowski et al. 2004; Cabała 2005). In the Tatra National Park it was previously found in the Staw Toporowy Niżni and Staw Toporowy Wyżni peat bogs.

Stomatocyst 29, Duff \& Smol 1989 emend. Zeeb \& Smol 1993 (Fig. 3)
Negative number: ZO/d-14.

Number of specimens: 2.

Locality: Żabie Oko lake, sediment from the bottom (0-10 $\mathrm{cm}$ deep).

Description: This stomatocyst is a smooth and spherical, $3.9 \mu \mathrm{m}$ in diameter. The pore is a concave, $0.3 \mu \mathrm{m}$ in diameter.

References: This stomatocyst has been found in Canada, U.S.A., Greenland (Duff et al. 1995), central Europe (Facher et al. 1996a), Austria (Kamenik et al. 2001), the Spanish part of Pyrenees (Pla 2001), Poland (Cabała 2002) and in Svalbard lakes (Betts-Piper et al. 2004).

Stomatocyst 22, Hansen 2001 (Figs 4-5)

Negative number: MO/r-08 (forma A), MO/d-06 (forma B) Number of specimens: 5 .

Locality: Morskie Oko lake, sediment from the bottom (0$10 \mathrm{~cm}$ deep) and water squeezed from plants.

Description: This stomatocyst is an oval to obovate, 8.1$8.4 \times 7.1-7.9 \mu \mathrm{m}$. The pore is deep with a planar pseudoannulus, $0.5-0.7 \mu \mathrm{m}$ in diameter.

Notes: The shape of the cyst body is obovate, not spherical as in original description. The ornamentation was variable in various specimens, some of them were smooth while others have scattered small verrucae. Therefore I propose to divide them into two formae as follows:

Forma A: The cyst body is unornamented, and its surface is completely smooth (Fig. 4).

**Forma B, Cabała J., this paper: This forma is very similar to forma A, but is ornamented with verrucae (Fig. 5).

References: Stomatocyst 22, Hansen 2001 (equivalent to Forma A) has been found in the Azores (Hansen 2001) and in Poland in the Staw Toporowy Wyżni peat bog in the Tatra National Park (Cabała 2005).

\section{With a collar:}

*Stomatocyst 53, Duff \& Smol 1991 (Fig. 6)

Negative number: ZO/d-13.

Number of specimens: 3 .

Locality: Żabie Oko lake, sediment from the bottom (0-10 cm deep).

Description: This stomatocyst is a smooth and spherical to slightly oblate, 5.7-6.3 $\mu \mathrm{m}$ in diameter. The pore is regular, $0.6 \mu \mathrm{m}$ in diameter. The collar is slightly cylindrical to obconical, 3.0-3.2 $\mu \mathrm{m}$ in diameter and 0.5-0.6 $\mu \mathrm{m}$ in height. References: This stomatocyst has been found in Canada, U.S.A. (Duff et al. 1995) and central Europe (Facher et al. 1996a).

Stomatocyst 308, Brown \& Smol in Brown et al. 1997 (Fig. 7)

Negative number: ZO/d-17.

Number of specimens: 2.

Locality: Żabie Oko lake, sediment from the bottom (0-10 cm deep).

Description: This stomatocyst is a smooth and spherical, 8.0-8.4 $\mu \mathrm{m}$ in diameter. The pore is concave, 0.6-0.7 $\mu \mathrm{m}$ in diameter. The collar is conical, 2.5-2.9 $\mu \mathrm{m}$ in diameter and $0.4 \mu \mathrm{m}$ in height.

Note: This stomatocyst is distinguished from stomatocyst 146, Zeeb \& Smol (after Duff et al. 1995) on the basis of collar morphology, and from stomatocyst 17, van de Vijver \& Beyens 1997a on the basis of cyst ornamentation. 

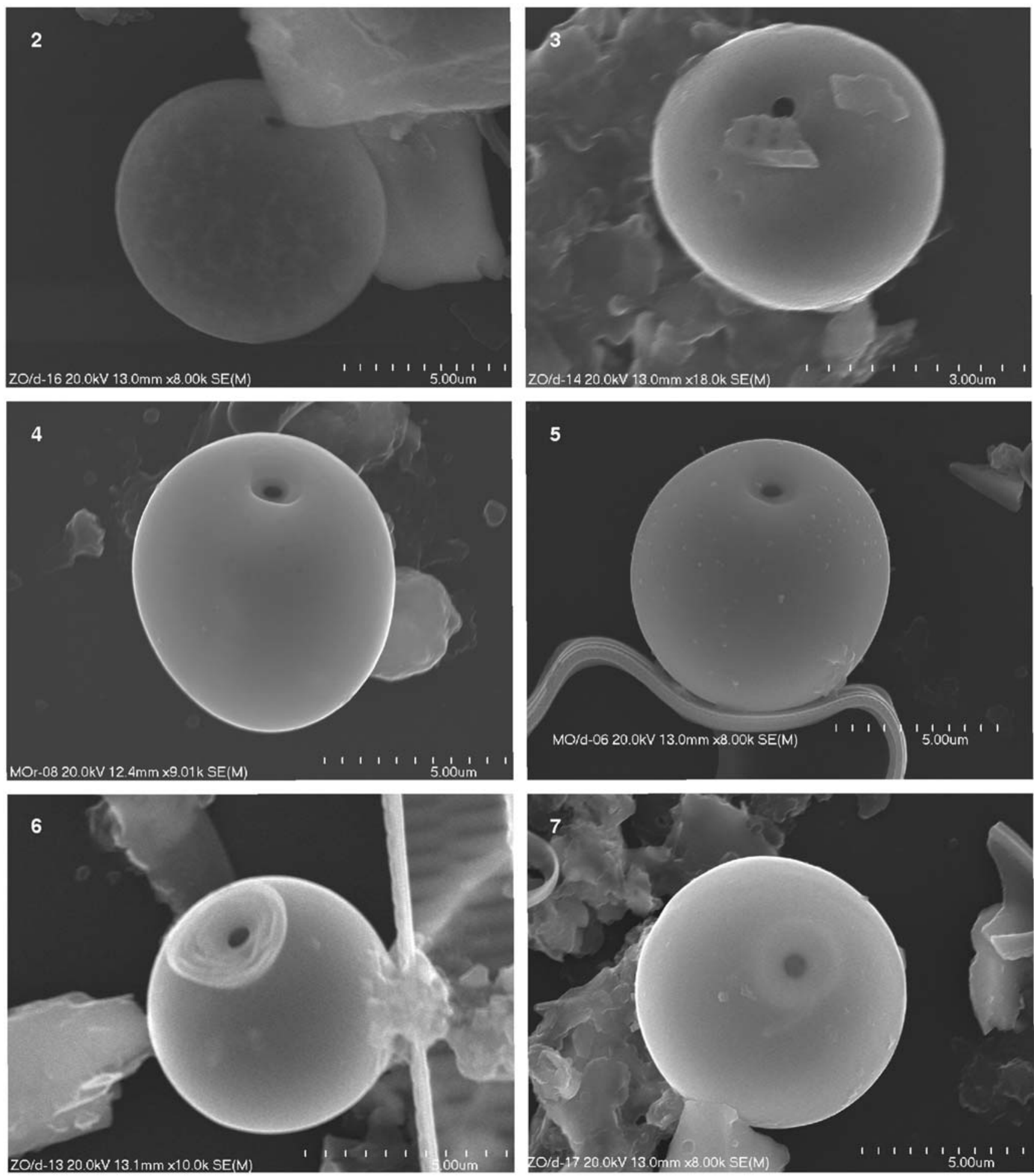

Figs 2-7.

Fig. 2. Stomatocyst 9. Fig. 3. Stomatocyst 29. Fig. 4. Stomatocyst 22 forma A. Fig. 5. Stomatocyst 22 forma B. Fig. 6. Stomatocyst 53. Fig. 7. Stomatocyst 308.

References: This stomatocyst has been found in Canada, Siberia (Wilkinson et al. 2001), Svalbard lakes (Betts-Piper et al. 2004) and in Poland where it was recorded in the Staw Toporowy Niżni and Staw Toporowy Wyżni peat bogs (Cabała and Piątek 2004; Cabała 2005).

*Stomatocyst cf. 322, Pla 2001 (Fig. 8)

Negative number: ZO/d-04.
Number of specimens: 1 .

Locality: Żabie Oko lake, sediment from the bottom (0-10 cm deep).

Description: This stomatocyst is a smooth and oblate, 5.2 $\mu \mathrm{m}$ in diameter. The pore is regular, $0.5 \mu \mathrm{m}$ in diameter, and set within the ornamented planar annulus. No primary collar. The secondary collar is wide, $2.8 \mu \mathrm{m}$ in diameter and $0.3 \mu \mathrm{m}$ in height. 

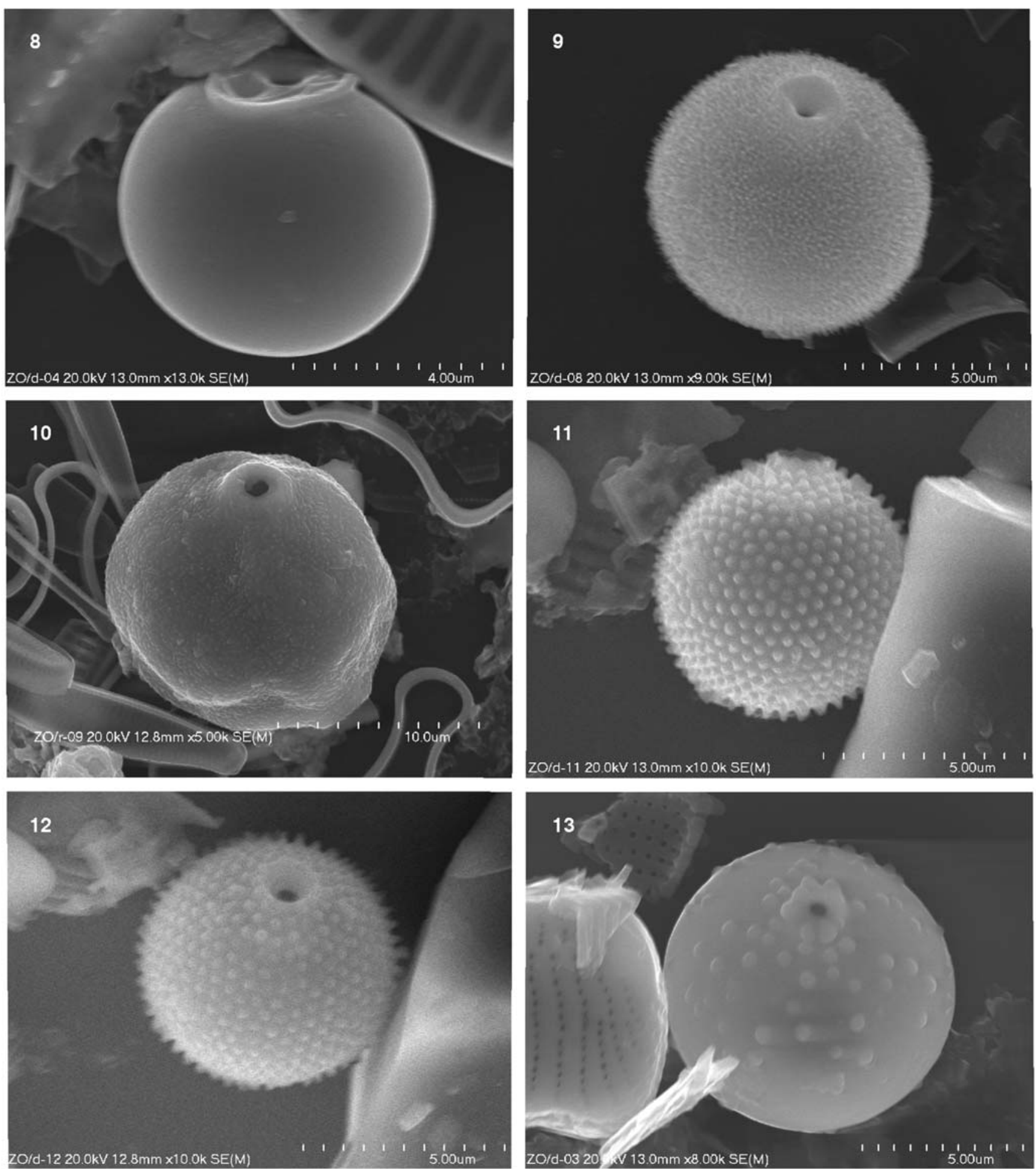

Figs 8-13.

Fig. 8. Stomatocyst cf. 322. Fig. 9. Stomatocyst 77. Fig. 10. Stomatocyst \#29. Figs 11-12. Stomatocyst 210. Fig. 13. Stomatocyst 136.

Notes: This specimen is provisionally attributed to stomatocyst 322, Pla 2001 from which it differs by absence of the primary collar. Furthermore, the planar annulus is more ornamented and the secondary collar is more regular than in the original description (Pla 2001).

References: This stomatocyst has been found in the Spanish part of Pyrenees (Pla 2001).

\section{Ornamented stomatocysts}

With scabrae:

*Stomatocyst 77, Duff \& Smol 1991 in Wilkinson et al. 2001 (Fig. 9)

Negative number: ZO/d-08.

Number of specimens: 2.

Localities: Morskie Oko lake, water squeezed from plants; Żabie Oko lake, sediment from the bottom (0-10 cm deep). Description: This stomatocyst is spherical, 7.0-7.5 $\mu \mathrm{m}$ in 

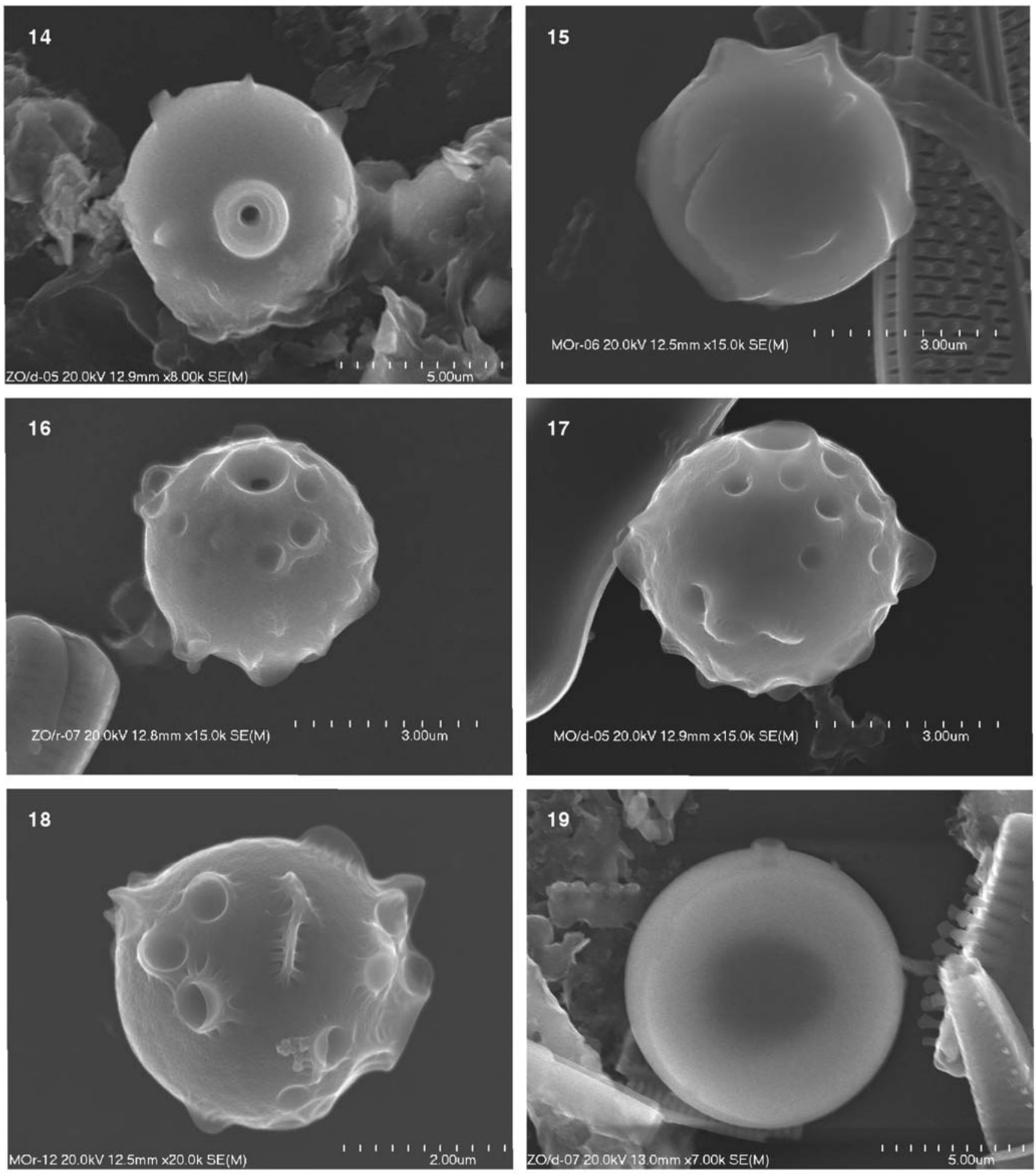

Figs 14-19.

Fig. 14. Stomatocyst cf. 63. Fig. 15. Stomatocyst 79. Figs 16-18. Stomatocyst 232 forma B. Fig. 19. Stomatocyst 28.

diameter. The pore is regular, 0.4 um in diameter. The collar is conical to cylindrical, $1.7 \mu \mathrm{m}$ in diameter and 0.3 $\mu \mathrm{m}$ in height. The cyst surface is ornamented with minute scabrae elements, $0.1 \mu \mathrm{m}$ in diameter and $0.2-0.3 \mu \mathrm{m}$ in height.

References: This stomatocyst has been found in Canada (Wilkinson et al. 2001), central Europe (Facher et al. 1996a) and in South Georgia, Subantarctic (van de Vijver et al. 2000).
**Stomatocyst \#29, Cabała J., this paper (Fig. 10)

Negative number: Cabała J., negative ZO/r-09, Fig. 10.

Number of specimens: 1 .

Locality: Żabie Oko lake, water squeezed from plants.

Description: This stomatocyst has irregular shape but slightly pyramidal, $13.8 \mu \mathrm{m}$ in diameter. The pore is regular to slightly concave, $1.1 \mu \mathrm{m}$ in diameter. The collar is conical with a rounded apex and sloping inner margin, 3.3 $\mu \mathrm{m}$ in diameter and $0.8 \mu \mathrm{m}$ in height. The cyst body is ornamented with scabrae, $0.1 \mu \mathrm{m}$ in diameter, covering the entire cyst body, including the outer collar margin. 

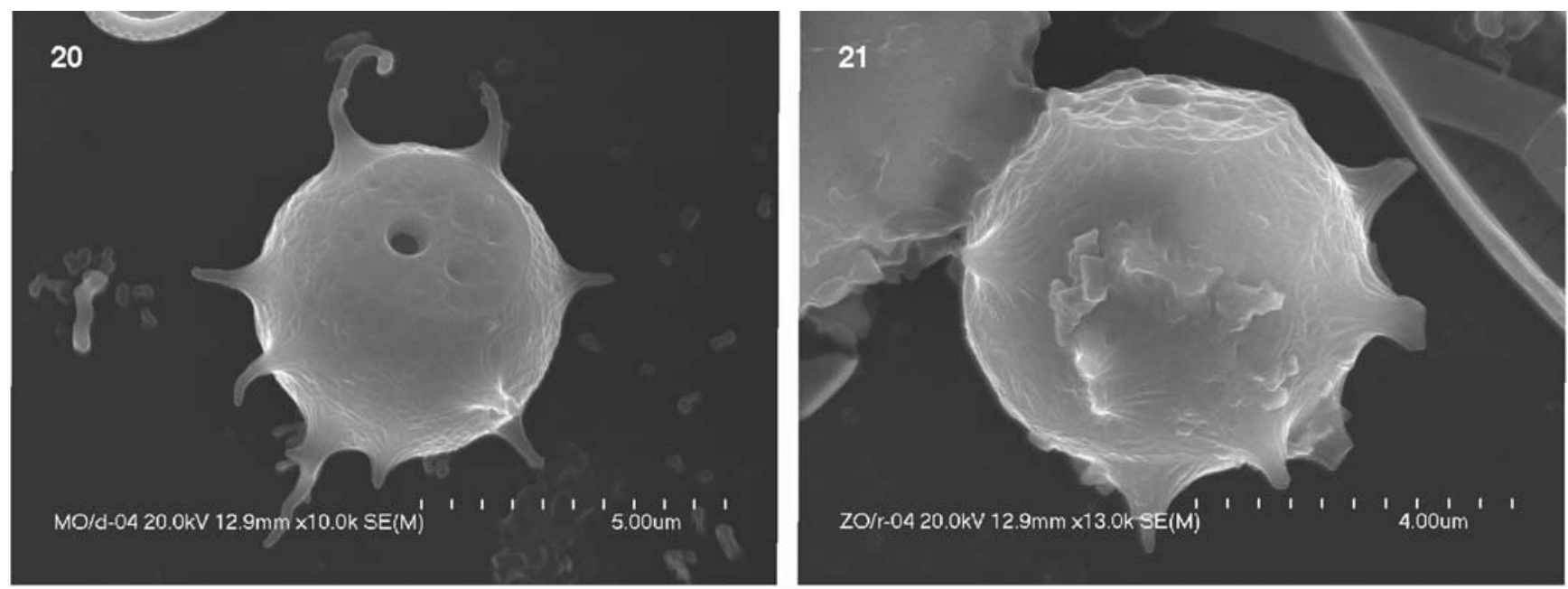

Figs 20-21. Stomatocyst \#30.

Notes: This stomatocyst is distinguished from stomatocyst 388 , Pla 2001 on the basis of cyst body size and of collar morphology; from stomatocyst 321, Pla 2001 on the basis of size and ornamentation. Ornamentation in this latter morphotype forms randomly oriented scabrae ridges.

With conula:

Stomatocyst 210, Duff \& Smol 1994 (Figs 11-12)

Negative number: ZO/d-11.

Number of specimens: 3 .

Locality: Żabie Oko lake, sediment from the bottom (0-10 $\mathrm{cm}$ deep) and water squeezed from plants.

Description: This stomatocyst is spherical, 5.9-6.2 $\mu \mathrm{m}$ in diameter. The pore is concave, $0.4-0.5 \mu \mathrm{m}$ in diameter. The collar is cylindrical, 1.3-1.6 $\mu \mathrm{m}$ in diameter and 0.2-0.4 $\mu \mathrm{m}$ in height. The cyst surface is ornamented with conula, $0.2-0.3 \mu \mathrm{m}$ in diameter and $0.2-0.3 \mu \mathrm{m}$ in height.

References: This stomatocyst has been found in Canada, U.S.A., Poland (Duff et al. 1995) and the Spanish part of Pyrenees (Pla 2001).

*Stomatocyst 136, Kamenik \& Schmidt in Kamenik et al. 2001 (Fig. 13)

Negative number: ZO/d-03.

Number of specimens: 3 .

Localities: Morskie Oko lake, water squeezed from plants; Żabie Oko lake, sediment from the bottom (0-10 cm deep) and water squeezed from plants.

Description: This stomatocyst is a spherical, 8.6-10.0 $\mu \mathrm{m}$ in diameter. The pore is slightly concave, $0.4-0.5 \mu \mathrm{m}$ in diameter. The collar is cylindrical to obconical, 1.8-2.3 $\mu \mathrm{m}$ in diameter and 0.4-0.6 $\mu \mathrm{m}$ in height, consists of 7-8 verrucae/conula. The cyst surface is ornamented with conula, 0.2-0.5 $\mu \mathrm{m}$ in diameter and 0.2-0.3 $\mu \mathrm{m}$ in height, in an irregular pattern on the anterior hemisphere.

References: This stomatocyst has been found in a high alpine lake in Austria (Kamenik et al. 2001).

\section{With spines:}

*Stomatocyst cf. 63, Facher \& Schmidt 1996a (Fig. 14)

Negative number: ZO/d-05.

Number of specimens: 2 .
Locality: Żabie Oko lake, sediment from the bottom (0-10 cm deep).

Description: This stomatocyst is spherical, 7.1-7.3 $\mu \mathrm{m}$ in diameter. The pore is regular, $0.6 \mu \mathrm{m}$ in diameter. The collar is conical, 2.0-2.2 $\mu \mathrm{m}$ in diameter and $0.6 \mu \mathrm{m}$ in height. The cyst surface is ornamented with spines, which seem to be broken.

Notes: This stomatocyst is smaller than in the original description (10-12 $\mu \mathrm{m}$ in diameter) and the collar is conical not cylindrical (Facher and Schmidt 1996a).

References: This stomatocyst has been found in central Europe (Facher and Schmidt 1996a).

With ridges:

Stomatocyst 79, Facher \& Schmidt 1996a (Fig. 15)

Negative number: MO/r-06.

Number of specimens: 2.

Locality: Morskie Oko lake, water squeezed from plants. Description: This stomatocyst is spherical, $4.2 \mu \mathrm{m}$ in diameter. The pore is not visible. The collar is cylindrical to slightly obconical, $2.0 \mu \mathrm{m}$ in diameter and $0.4 \mu \mathrm{m}$ in height. The cyst surface is ornamented with ridges, 0.9-1.5 $\mu \mathrm{m}$ in length and 0.2-0.3 $\mu \mathrm{m}$ in height.

Notes: This stomatocysts is distinguished from stomatocyst 33, Duff \& Smol 1989 on the basis of ornamentation and from stomatocyst 113, Zeeb et al. 1990 on the basis of collar morphology.

References: This stomatocyst has been found in central Europe (Facher et al. 1996a) and in Poland in the Staw Toporowy Wyżni peat bog in the Tatra National Park (Cabała 2005).

\section{With compound ornamentation}

*Stomatocyst 232 forma B, Duff \& Smol 1994 (Figs 16$-18)$

Negative number: ZO/r-07.

Number of specimens: 26.

Localities: Morskie Oko lake, sediment from the bottom (0-10 cm deep) and water squeezed from plants; Żabie Oko lake, sediment from the bottom $(0-10 \mathrm{~cm}$ deep) and water squeezed from plants.

Description: This stomatocyst is spherical, 3.6-4.4 $\mu \mathrm{m}$ in diameter. The pore is conical, 0.3-0.4 $\mu \mathrm{m}$ in diameter. The 
collar is conical, 1.1-1.4 $\mu \mathrm{m}$ in diameter and 0.2-0.3 $\mu \mathrm{m}$ in height. The cyst surface has compound ornamentation. Circular depressions, 0.4-0.5 $\mu \mathrm{m}$ in diameter, are located in the anterior hemisphere. Ridges, 0.5-1.3 $\mu \mathrm{m}$ in length, 0.2$-0.6 \mu \mathrm{m}$ in height and $0.2-0.3 \mu \mathrm{m}$ in wide are located in the posterior hemisphere or subequatorially. The surface of cyst body is finely reticulate between circular depressions and ridges.

References: This stomatocyst has been found in Canada, U.S.A. (Duff et al. 1995), the Spanish part of Pyrenees (Pla 2001) and in Svalbard lakes (Betts-Piper et al. 2004).

Stomatocyst 28, Cabała J. 2005 (Fig. 19)

Negative number: ZO/d-07.

Number of specimens: 1 .

Locality: Żabie Oko lake, sediment from the bottom (0-10 cm deep).

Description: This stomatocyst is spherical, $9.6 \mu \mathrm{m}$ in diameter. The pore is not visible. The collar is cylindrical, 1.1 $\mu \mathrm{m}$ in diameter and $0.5 \mu \mathrm{m}$ in height, with curved margin (apex $1.6 \mu \mathrm{m}$ wide).

Notes: This specimen represents immature stomatocyst 28, Cabała J. 2005. The mature stomatocyst surface is ornamented with scabrae and a number of circuli with a central depression and a diameter of 0.5-0.6 $\mu \mathrm{m}$ (Cabała 2005). Stomatocyst 28, Cabała J. 2005 is distinguished from stomatocyst 103, Duff \& Smol (after Wilkinson et al. 2001) on the basis of ornamentation and collar morphology, and from stomatocyst 11, Facher \& Schmidt 1996a on the basis of collar morphology.

References: This stomatocyst has been originally described from the Staw Toporowy Wyżni peat bog in the Tatra National Park in Poland (Cabała 2005).

**Stomatocyst \#30, Cabała J., this paper (Figs 20-21)

Negative number: Cabała J., negative MO/d-04, Fig. 20.

Number of specimens: 4 .

Localities: Morskie Oko lake, sediment from the bottom (0-10 cm deep) and water squeezed from plants; Żabie Oko lake, water squeezed from plants.
Description: This stomatocyst is spherical, 4.7-5.2 $\mu \mathrm{m}$ in diameter. The pore is regular, $0.4-0.5 \mu \mathrm{m}$ in diameter, which set asymmetrically within the ornamented planar annulus separating the primary collar from the wide secondary collar. The primary and secondary collars are very low. The cyst surface has compound ornamentation, low, irregular to triangular reticulum and spines, 1.2-2.3 $\mu \mathrm{m}$ long and 0.2-0.4 $\mu \mathrm{m}$ wide. Spines are wider at base $(0.6-0.9 \mu \mathrm{m})$ and located over the surface.

Notes: This stomatocyst is distinguished from stomatocyst 83, Duff \& Smol 1991 on the basis of ornamentation and collar morphology; from stomatocyst 85, Duff \& Smol 1991 on the basis of ornamentation.

\section{DISCUSSION}

A total of 16 different stomatocysts were recorded from Morskie Oko and Żabie Oko lakes. Of these six morphotypes are new to Poland, and two morphotypes plus one forma are new to science. The newly described morphotypes are highly unique and belong to the group of ornamented stomatocysts. In the case of stomatocyst 22, Hansen 2001 it was necessary to split it into two formae differing by type of cyst surface. Forma A is smooth while forma B, which was described as new, has cyst surface ornamented with verrucae.

The number of stomatocysts in the two lakes differed significantly, in the Morskie Oko lake only seven morphotypes were observed while in the Żabie Oko lake their number was higher, comprising thirteen morphotypes (Table 1). Although the material for studies were taken from surface water, water from beneath the surface, sediment from the bottom of the lakes and water squeezed from algal mats and mosses, the stomatocysts were found only in materials collected from sediment and squeezed from water plants. It may depend on the character of cyst surface (smooth or ornamented), which enable them to inhabit particular microhabitats. It is also possible that stomatocysts are falling down to the bottom of the lake because they are "heavy"

TABLE 1. List of identified stomatocysts observed in the Morskie Oko lake and comparison with stomatocysts' composition of Żabie Oko lake, along with their primary reference(s) and their occurrence in various parts of the lakes.

\begin{tabular}{|c|c|c|c|c|}
\hline \multirow[b]{2}{*}{ Stomatocysts } & \multicolumn{2}{|c|}{ Morskie Oko lake } & \multicolumn{2}{|c|}{ Żabie Oko lake } \\
\hline & $\begin{array}{l}\text { Sediment from } \\
\text { the bottom } \\
0-10 \mathrm{~cm} \text { deep }\end{array}$ & $\begin{array}{l}\text { Water squeezed } \\
\text { from water plants }\end{array}$ & $\begin{array}{l}\text { Sediment from } \\
\text { the bottom } \\
0-10 \mathrm{~cm} \text { deep }\end{array}$ & $\begin{array}{l}\text { Water squeezed } \\
\text { from water plants }\end{array}$ \\
\hline 9, Duff \& Smol 1988 emend. Zeeb \& Smol 1993 & & & + & \\
\hline 29, Duff \& Smol 1989 emend. Zeeb \& Smol 1993 & & + & + & \\
\hline 22, Hansen 2001, forma A & + & & & \\
\hline 22, Hansen 2001, \#forma B, Cabała J., this paper & + & & & \\
\hline 53, Duff \& Smol 1991 & & & + & \\
\hline 308, Brown \& Smol in Brown et al. 1997 & & & + & \\
\hline cf. 322, Pla 2001 & & & + & \\
\hline 77, Duff \& Smol 1991 in Wilkinson et al. 2001 & & + & + & \\
\hline \#29, Cabała J., this paper & & & & + \\
\hline 210, Duff \& Smol 1994 & & & + & + \\
\hline 136, Kamenik \& Schmidt 2001 & & + & + & + \\
\hline cf. 63, Facher \& Schmidt 1996a & & & + & \\
\hline 79, Facher \& Schmidt 1996a & & + & & \\
\hline 232 forma B, Duff \& Smol 1994 & + & + & + & + \\
\hline 28, Cabała J. 2005 & & & + & \\
\hline \#30, Cabała J., this paper & + & + & & + \\
\hline
\end{tabular}


TABLE 2. Chemical and physical parameters of the Morskie Oko and Żabie Oko lakes in the Tatra National Park.

\begin{tabular}{|c|c|c|}
\hline Chemical and physical parameters & $\begin{array}{l}\text { Morskie Oko } \\
\text { lake }\end{array}$ & $\begin{array}{l}\text { Żabie Oko } \\
\text { lake }\end{array}$ \\
\hline Ammonium $\left(\mathrm{NH}_{4}^{+}\right) \mathrm{mg} \cdot \mathrm{l}^{-1}$ & $\begin{array}{l}\text { below } \\
\text { measuring range }\end{array}$ & 0.4 \\
\hline Nitrite $\left(\mathrm{NO}_{2}^{-}\right) \mathrm{mg} \cdot \mathrm{l}^{-1}$ & 0.025 & 0.15 \\
\hline Nitrate $\left(\mathrm{NO}_{3}^{-}\right) \mathrm{mg} \cdot \mathrm{l}^{-1}$ & 10.0 & $\begin{array}{l}\text { below } \\
\text { measuring range }\end{array}$ \\
\hline $\mathrm{pH}$ & 7.0 & 7.0 \\
\hline Total hardness $\mathrm{mmol} \cdot \mathrm{l}^{-1}$ & 0.3 & 0.2 \\
\hline $\begin{array}{l}\text { Carbonate hardness } \\
\text { (acid-binding capacity) } \mathrm{mmol} \cdot \mathrm{l}^{-1}\end{array}$ & 1.2 & 1.2 \\
\hline Residual hardness $\mathrm{mmol} \cdot \mathrm{l}^{-1}$ & 0.02 & 0.02 \\
\hline Temperature of water ${ }^{\circ} \mathrm{C}$ & 19.0 & 18.0 \\
\hline Phosphate $\left(\mathrm{PO}_{4}{ }^{3-}\right) \mathrm{mg} \cdot \mathrm{l}^{-1}$ & $\begin{array}{l}\text { below measuring } \\
\text { range }\end{array}$ & $\begin{array}{l}\text { below measuring } \\
\text { range }\end{array}$ \\
\hline
\end{tabular}

and cannot freely float on the water, especially when they have not "airfolis" (comp. Adam and Mahood 1981; Cabała and Piątek 2004).

Physical-chemical parameters in both lakes were similar, with the exception of occurrence of nitrate ions $\left(\mathrm{NO}_{3}^{-}\right)$: $10.0 \mathrm{mg} \cdot \mathrm{l}^{-1}$ in the Morskie Oko lake versus below a measuring range in the Żabie Oko lake (Table 2). In spite of these only four stomatocysts occurred in both lakes: stomatocyst 77, Duff \& Smol 1991, stomatocyst 136, Kamenik \& Schmidt 2001, stomatocyst 232 forma B, Duff \& Smol 1994, and stomatocyst \#30, Cabała J. The most abundant and frequent morphotype known from both lakes was stomatocyst 232 forma B. The remaining stomatocysts occurred rarely (Table 1$)$.

The first reports about chrysophycean stomatocysts, which were found in Morskie Oko lake were of authorship of Wołoszyńska (1939) and Wasylik (1965). Wołoszyńska (1939) found one taxon of Mallomonas akrokosmos fo. tatrica in the lake and she observed stomatocysts, which were produced by this species. Wołoszyńska (1939) wrote that stomatocysts produced by M. akrokomos fo. tatrica are oval, $10 \mu \mathrm{m}$ in long and $8 \mu \mathrm{m}$ in wide, with smooth surface. In my opinion this cyst refers to stomatocyst 22, Hansen 2001, forma A $(8.1-8.4 \times 7.1-7.9 \mu \mathrm{m})$, identified by me in the Morskie Oko lake. Previously this forma was found in the Azores (Hansen 2001), and in Poland in the Staw Toporowy Wyżni peat bog (Cabała 2005) as stomatocyst 22, Hansen. Unfortunately, I did not find any species of Mallomonas and other golden-brown algae both in Morskie Oko lake and Staw Toporowy Wyżni peat bog. Wasylik (1965) provided brief information about 25 stomatocyst co-occurring with algae in the Morskie Oko lake. He included only some line drawings of cysts without LM and/or SEM micrographs and detailed descriptions. However, these drawings are useless for determination of morphotypes. The only exception is the cyst, which Wasylik (1965) illustrated as having diameter of cyst body: $6 \mu \mathrm{m}$, and diameter of pore: $1 \mu \mathrm{m}$ (his Fig. 3 on Plate $1-$ this figure is in- correctly described as Melosira distans because of typographic error). In my opinion this cyst is similar to stomatocyst 9, Duff \& Smol 1988.

The number of chrysophycean stomatocysts recorded from the Tatra National Park is currently estimated to comprise 83 extant morphotypes, of these 19 plus one forma are new to science. This number will certainly increase with progress of ongoing studies in other alpine lakes of the Tatra Mts.

\section{ACKNOWLEDGEMENTS}

I am grateful to the anonymous reviewer for valuable advice and helpful remarks on the manuscript, to Professor Konrad Wołowski (Kraków) for valuable comments on the manuscript, to Anna Łatkiewicz (Kraków) for help in preparing the SEM micrographs, and to my colleague Dr. Marcin Piątek (Kraków) for fruitful discussion and his help with the English translation. This work was supported by the State Committee for Scientific Research (MNiI) for the years 2005-2007, grant no. 2 P04G 023 28, and by W. Szafer Foundation of Polish Botany.

\section{LITERATURE CITED}

ADAM D.P., MAHOOD A.D. 1981. Chrysophyte cysts as potential environmental indicators. Geol. Soc. Amer. Bull, Part I, 92: 839-844.

BETTS-PIPER A.M., ZEEB B.A., SMOL J.P. 2004. Distribution and autecology of chrysophyte cysts from high Arctic Svalbard lakes: preliminary evidence of recent environmental change. J. Paleolimnol. 31: 467-481.

BILÝ J. 1941. Přispevek ku poznáni kveteny rozsivek Vysokých Tater. Práce Mor. Přir. Spol. 13 (2): 1-12. (in Czech)

BROWN K.M., ZEEB B.A., SMOL J.P., PIENITZ R. 1997. Taxonomic and ecological characterization of chrysophyte stomatocysts from northwestern Canada. Canad. J. Bot. 75: 842-863.

CABAŁA J. 2002. Chrysophyceae stomatocysts from Budzyń peat bog (Kraków-Częstochowa Upland, Poland). Polish Bot. J. 47 (1): 21-35.

CABAŁA J. 2003a. New and rare morphotypes of chrysophycean stomatocysts from Poland. Nova Hedwigia 77: 99-107.

CABAŁA J. 2003b. Three morphotypes of chrysophycean stomatocysts from Poland. Polish Bot. J. 48 (1): 13-16.

CABAŁA J. 2005. Chrysophyte stomatocysts from Staw Toporowy Wyżni peat bog in the Tatra National Park, Poland. Archiv für Hydrobiol.157/Algol. Studies 116: 129-146.

CABAŁA J., PIĄTEK M. 2004. Chrysophycean stomatocysts from Staw Toporowy Niżni lake in the Tatra National Park, Poland. Ann. Limnol. 40 (2): 149-165.

CRONBERG G., SANDGREN C.D. 1986. A proposal for the development of standardised nomenclature and terminology for chrysophycean statospores. In: J. Kristiansen, R.A. Andersen (eds): Chrysophytes: aspects and problems: pp. 317-328. Cambridge University Press, Cambridge.

DUFF K.E., SMOL J.P. 1988. Chrysophycean stomatocysts from the postglacial sediments of a High Arctic lake. Canad. J. Bot. 66: 1117-1128.

DUFF K.E., SMOL J.P. 1989. Chrysophycean stomatocysts from the postglacial sediments of Tasikutaaq Lake, Baffin Island, N.W.T. Canad. J. Bot. 67: 1649-1656.

DUFF K.E., SMOL J.P. 1991. Morphological descriptions and stratigraphic distributions of the chrysophycean stomatocysts from a recently acidified lake (Adirondack Park, N.Y.). J. Paleolimnol. 5: 73-113. 
DUFF K.E., SMOL J.P. 1994. Chrysophycean cyst flora from British Columbia (Canada) lakes. Nova Hedwigia 58: 353-389.

DUFF K.E., ZEEB B.A., SMOL J.P. 1995. Atlas of chrysophycean cysts. Developments in Hydrobiology 99: 1-189. Kluwer Academic Publishers, Dordrecht.

FACHER E., SCHMIDT R. 1996a. A siliceous chrysophycean cyst-based $\mathrm{pH}$ transfer function for Central European lakes. J. Paleolimnol. 16: 275-321.

FACHER E., SCHMIDT R. 1996b. Application of chrysophyte sediment trap data and a cyst-based $\mathrm{pH}$ transfer function to annually laminated sediments (Lake Plešné, Bohemia, Czech Republik). Beih. Nova Hedwigia 114: 219-231.

GUTWIŃSKI R. 1909. Flora algarum montium Tatrensium. Bull. Inter. PAcad. Sci. Cracovie 34: 415-560.

GUTWIŃSKI R. 1913. Ueber die Algenflora und das Plankton des Tatra-Sees "Morskie Oko". Kosmos 38: 1426-1437. (in Polish with German summary).

HANSEN P. 2001. Chrysophyte stomatocysts in the Azores biogeographical implications and 110 new morphotypes. Opera Bot. 138: 1-96.

KAMENIK C., SCHMIDT R., KOINIG K.A., AGUSTÍ-PANAREDA A., THOMPSON R., PSENNER R. 2001. The chrysophyte stomatocyst composition in a high alpine lake (Gossenköllesee, Tyrol, Austria) in relation to seasonality, temperature and land-use. Beih. Nova Hedwigia 122: 1-22.

KAWECKA B. 1965. Communities of Bentic Algae in the River Białka and in its Tatra Tributaries the Rybi Potok and Roztoka. Komitet Zagosp. Ziem Górskich, PAN 11: 113-127.

KAWECKA B. 1966. Aufwushsalgen aut Potamogeton sp. im See Morskie Oko. Acta Hydrobiol. 8 (3-4): 321-328. (in Polish with German summary).

KAWECKA B. 1977. Biocenosis of a high mountain stream under the influence of tourism. 3. Attached algae communities in the stream Rybi Potok (the High Tatra Mts., Poland) polluted with domestic sewage. Acta Hydrobiol. 19 (3): 271-292.

MROZIŃSKA T., OLECH M., MASSALSKI A. 1998. Cysts of Chrysophyceae from King George Island (South Shetland Islands, Antarctica). Polish Polar Res. 19 (3/4): 205-210.

PLA S. 2001. Chrysophycean cysts from the Pyrenees. Biblioth. Phycol. 109: 1-179.

SIEMIŃSKA J. 1958. Bulbochaete basispora Wittrock et Lundel, a new species for the Tatra Mountains and for Poland. Fragm. Florist. Geobot. 3 (2): 151-153. (in Polish with English summary).

SIEMIŃSKA J. 1962. Badania algologiczne w Tatrach. In: W. Szafer (ed.): Tatrzański Park Narodowy. Polska Akademia Nauk, Zakład Ochrony Przyrody 21: 305-316. (in Polish with English summary).

SIEMIŃSKA J. 1970a. Niektóre aspekty badań Morskiego Oka w Tatrach. Kosmos A 2 (103): 173-197.

SIEMIŃSKA J. 1970b. Some species of Chrysophyceae from Morskie Oko Lake in the Tatra Mts. Fragm. Florist. Geobot. 16 (1): 183-186.

SZKLARCZYK-GAZDOWA C. 1960. Phytoplankton of some Tatra lakes. Acta Soc. Bot. Polon. 29 (4): 597-624. (in Polish with English summary).
VAN DE VIJVER B., BEYENS L. 1997a. The subfossil Chrysophyte cyst flora of some peat samples from Kerguelen Islands. Arch. Protistenk. 148: 491-503.

VAN DE VIJVER B., BEYENS L. 1997b. The Chrysophyte stomatocyst flora of the moss vegetation from Strřmness Bay Area, South Georgia. Arch. Protistenk. 148: 505-520.

VAN DE VIJVER B., BEYENS L. 2000. Chrysophycean stomatocysts from freshwater habitats of the Strømness Bay area, South Georgia, Antarctica. Canad. J. Bot. 78: 88-97.

VOROBYOVA S.S., POMAZKINA G.V., BARANOVA E.YU. LIKHOSHWAY YE.V., SANDGREN C.D. 1996. Chrysophycean cysts (stomatocysts) from Lake Baikal and Irkutsk. J. Paleolimnol. 15: 272-277.

WASYLIK K. 1965. Remnants of algae in bottom sediments of the lakes Wielki Staw and Morskie Oko in the Tatra Mountains. Komitet Zagosp. Ziem Górskich PAN 11: 39-58.

WILKINSON A.N., ZEEB B.A., SMOL J.P. 2001. Atlas of chrysophycean cysts. Volume II. Developments in Hydrobiology 157: 1-169. Kluwer Academic Publishers, Dordecht.

WIT-JÓŹWIKOWA K., ZIEMOŃSKA Z. 1962. The hydrography of the Polish Tatras. In: W. Szafer (ed.): Tatrzański Park Narodowy. Polska Akademia Nauk, Zakład Ochrony Przyrody 21: 125-138. (in Polish with English summary).

WOŁOSZYŃSKA J. 1919. Glony stawów i młak tatrzańskich. Część I. Rozprawy Wydziału Matematyczno-Przyrodniczego Akademii Umiejętności, Seria III, Dział B - Nauki Biologiczne 8: 315-324.

WOŁOSZYŃSKA J. 1934. Asterionella formosa Hass. var. tatrica n. var. in den Tatraseen. Acta Soc. Bot. Pol., Suppl. 11: 137-152. (in Polish with German summary).

WOŁOSZYŃSKA J. 1935. Die Algen der Tatraseen und Tümpel. II. Über zwei Gymnodinien aus den Seen "Morskie Oko" und "Czarny Staw pod Rysami. Bull. Acad. Polonaise Sc. Letters, Cl. Sc. math.-nat., Ser. B, Sc. Nat. 1: 1-9.

WOŁOSZYŃSKA J. 1936. Die Algen der Tatraseen und Tümpel. III. Peridineen im Winterplankton eininger Tatraseen. Arch. Hydrobiol. et Icht. 10: 188-196.

WOŁOSZYŃSKA J. 1939. Die Algen der Tatraseen und Tümpel. IV. Mallomonas-Arten in den Tatraseen. Acta Soc. Bot. Pol. 16 (1): 29-39. (in Polish with German summary).

WOŁOSZYŃSKA J. 1952. Bruzdnice Tatr i Karpat Wschodnich. Acta Soc. Bot. Pol. 21 (1-2): 311-316.

WOŁOWSKI K., OBIDOWICZ A., WAWRZYCKA I. 2002. Pediastrum species (Chlorophyceae) in Quaternatry sediments of "Żabie Oko" in the Tatra Mts. Acta Palaeobot. 42 (1): 51-61.

WOŁOWSKI K., CABAŁA J., ZEEB B.A. 2004. Chrysophycean stomatocysts from a karstic sink-hole in the vicinity of the Staszów on the Małopolska Upland, Poland. Canad. J. Bot. 82 (9): 1330-1337.

ZEEB B.A., SMOL J.P. 1993. Chrysophycean stomatocyst flora from Elk Lake, Clearwater County, Minnesota. Canad. J. Bot. 71: 737-756.

ZEEB B.A., DUFF K.E., SMOL J.P. 1990. Morphological descriptions and stratigraphic profiles of chrysophycean stomatocysts from the recent sediments of Little Round Lake, Ontario. Nova Hedwigia 51: 361-380. 